\title{
Political Privileges in Late Feudal Society in France by the End of the 17th and the Beginning of the 18th Century and the Lessons for the Modern Times
}

\author{
Georgi Lyubenov Manolov \\ Department of Political Science, University of National and World Economy, Sofia, Republic of Bulgaria
}

Email address:

manolovi@gmail.com,info@vusi.bg

\section{To cite this article:}

Georgi Lyubenov Manolov. Political Privileges in Late Feudal Society in France by the End of the 17th and the Beginning of the 18th century and the Lessons for the Modern Times. Journal of Political Science and International Relations. Vol. 4, No. 2, 2021, pp. 41-47.

doi: $10.11648 /$ j.jpsir.20210402.13

Received: April 26, 2021; Accepted: May 15, 2021; Published: May 26, 2021

\begin{abstract}
This article examines the essence and nature of political privileges in the late feudal society (late 17 th-18th centuries in France), which is the main purpose of the analysis. A definition of political privileges has been formulated, on the basis of which their main manifestations during feudalism have been analyzed. The privileges are classified according to several basic criteria - historical origin, social sphere, legitimacy and political hierarchy of power. The genesis and development of the privileges in the French feudal society since the end of the 17th and the beginning of the 18th century were subjected to a synthesized analysis by revealing the key types of privileges then - the signoral and noble ones. Emphasis is placed on the numerous political privileges of the French royal family, the nobility and the religious clergy, who were the largest users of the system of privileges during this period. There are a number of illustrative examples of the enormous political, financial and corruption damage suffered by the French state from the illegitimate introduction of the system of privileges in absolutist France. A comparison with some privileges in politics that found a place in totalitarian socialist societies in the twentieth century has been made. On this basis, the nature of the privileges in the former socialist countries of Central and Eastern Europe, and in particular of their basic forms in "socialist" Bulgaria (1944-1989), is revealed in a comparative plan. Specific conclusions (and recommendations) about the nature, meaning and necessity of political privileges in modern societies have also been made.
\end{abstract}

Keywords: Political Privileges, Privileges, Feudal Society

\section{Introduction}

The privileges of politicians in all historical epochs have always caused a lot of controversies, disputes and scandal. This is because, whether they are legitimate or illegitimate, they constantly create some inequalities between people, insofar as they are part of the advantages of power. However, these inequalities have different social dimensions, but are most often perceived as something "extrajudicially" justified or as some kind of supreme injustice. Here, the norms of political representation and law are usually mixed, due to which a number of negative social attitudes are formed among the citizens towards the holders (political elite) of one or another managerial privilege. Therefore, we will first look at the essence of the concept of "political privileges", then analyze their manifestation in feudal France in the eighteenth century (partly in the so-called "socialist" societies) and finally draw the appropriate conclusions in the context of the historical period, as well as the significance of the problem in our time.

\section{The Concept of "Political Privileges"}

The term "privilege" ("privilegium" - from "privus" "outside", and "les", "leges" - "law") has Latin origins and its literal semantics means "something that is outside the law". In social practice, this term has acquired civil meaning and legitimacy as "the exclusive right and advantage of an entity (person, individual, group, class) over certain material property (and objects) and spiritual goods (and values)".

From such positions, the privileges in society can be determined in at least three aspects: in social - as some 
exclusive rights of one group of people over another group of people deprived of such rights [11] (p. 65 - 67), [5] (p. 176 $177)$; in legal - as a specific right or favorable legal position granted by the state to an authorized entity (or a very limited group of people) and distinguished by a feature that does not naturally presuppose such a legal situation [16] (p. 2 - 3); and in cultural terms - as an important part of the political culture of a society (ideas, values, traditions, etc.) in different historical epochs. In this sense, the French researcher Jacques Attali is absolutely right, who believes that privileges mean some benefits without legitimate grounds for the recipients, or such benefits that have no legal basis (...) and should therefore be excluded from the notion of political culture as something unfair in modern democratic societies.

As for their political nature, privileges could be defined as: exclusive rights and advantages of a small group of people (oligarchy, strata, class) over other groups of people (social groups, classes) who are deprived of such rights and advantages and which are possessed by some minority social community (group) due to its political power in the state.

Historically, these rights and advantages are imposed by the customs or laws of class societies, because privileges separate a group of people from the social whole, forming it into a small and extremely closed community (called "oligarchy" and "political elite").

Unlike law, where privileges are formed and motivated by the established legal (and legislative) order, with which all legal entities are engaged, including the state (through its institutions), this is not the case with political privileges. In this case, the deepest source (generator, motivator) of the various types of privileges is the political power itself, exercised by various personal or collective entities who exercise it (legitimately or illegitimately). Or, in the political sphere, privileges are always fueled by the "reservoir of power" regardless of the nature of the political regime (democratic, totalitarian, authoritarian). Moreover, political privileges are too often motivated by the "sole will of the power that grants it" (Iva Pushkarova), without the latter necessarily complying with the privileged rights that it itself grants them. That is, power and power resources in general, as well as sole power (and prerogatives) in particular, are the main engine of political privileges in the state. This is the key dividing line between political privileges and those in other public spheres, because without the functioning of political power there will be no privileges in politics.

We have already emphasized that with the help of privileges one or another minority group in politics secures and guarantees a number of its own advantages, the most important of which are: 1) the highest social status (oligarchic elite, stratum, stratum); 2) the most favorable use of material and spiritual goods (gains, benefits, advantages); 3) the brightest social autonomy (independence) from other social groups and strata (oligarchy, elite, community); 4) the most visible political domination over all other social communities (groups, strata, collectives); 5) the most advantageous legal treatment of a specific group of persons, differentiated according to a criterion specified in the laws (senior state positions, positions, ranks); 6) the easiest access to certain public goods (education, medical services, etc.) and to those that are not publicly available (luxury cars, high pensions, etc.); 7) best-regulated immunity (functional and full) as a guarantor against the types of legal responsibilities of privileged minority groups; and 8) the most striking material, property, material, spiritual, cultural, valuable and other inequalities between the different social groups in the country

We can get an even more complete idea of the scale of the privileges from their classification, which would have the following logical order:

I. According to the origin

1. Hereditary (by origin)

2. Acquired (by wealth, by education, by merit, by power, etc.) $[15]$ (p. 35)

II. According to the social sphere

1. Political

2. Economical

3. Cultural

4. Others

III. According to legitimacy

1. Legitimate (regulated)

2. Illegitimate (unregulated)

IV. According to the political hierarchy of power (and elite)

1. Of the oligarchy

2. Of the local elite (district, municipal)

3. At a low level (mayoral)

It is necessary to summarize, pointing out that regardless of the fact of regulation or non-regulation of privileges, their manifestation and existence in the political life of societies have always led to the uneven distribution of various social goods, giving undeserved advantage (and favoring) to individual citizens, unjustified redistribution of economic (material and financial) resources, etc. That is, all political privileges have always led to absolutely unjust and blatant inequalities in society, which have affected millions and millions of human beings at the expense of a handful of favored oligarchic elites (throughout human history).

\section{Feudal Political Privileges in the XVII and XVIII Centuries}

The emergence and development of privileges date back to the history of the slave-owning society, where they arose on the basis of property differences between people, and subsequently covered other social spheres. But privileges received their fullest development in the age of feudalism, and lost their class character under capitalism. With the emergence of bourgeois civil society, class privileges were abolished and replaced by the equality of all citizens before the law, which guaranteed "Equal rights for all, special privileges for none" (T. Jefferson). These privileges (the class ones) have prevailed in feudal societies for almost several centuries, leaving lasting traces on the functioning of some future social systems, so we will examine in more detail their specific nature and diversity in the era of absolutism. 
According to B. Gavrilov, absolutism in Europe in the XVII $^{\text {th }}$-XVIII ${ }^{\text {th }}$ centuries was characterized in general terms by the establishment of political regimes in which state power was exercised by a sovereign ruler over the entire territory of the respective state with the help of a military-bureaucratic machine under his unlimited power. This definition includes both the most developed absolutism - the French, and the most limited - that of the British Isles. In addition, power in the seventeenth century stemmed from origin and heredity, from unshakable privileged legitimacy, and by the middle of the eighteenth century the affirmation of the ideas of J. Harrington for the acquired power has already taken place.

In feudal society, privileges are based on the domination of class private property and the use of serf labour. On this basis, a certain structure of privileges grows and is fixed, which ensure the monopolization of a large part of the socially significant types of activity (management, protection of the external borders, etc.) by certain social groups. This monopolization of social activities is determined by the very social structure of feudal society, which hinders the vertical mobility of the population and establishes a constant reproduction of privileged social groups [19] (p. 59 - 60). The affiliation of people to these groups is determined by birth (by inheritance). Here the functions of each class are precisely defined and fixed by the customs and laws of feudal society and they are protected and guaranteed by the feudal state itself.

The system of privileges in feudal society has three characteristic features: first, it permeates all aspects of society; second, it is strictly regulated; and third, it is realized mainly in the sphere of consumption (on the basis of the relatively limited fund for consumption of material goods, which is created through the use of traditional manual labor). The third feature of feudal privileges is also characterized by the fact that the advantages of the feudal class in the field of consumption extend mainly to luxury items and to a much lesser extent on the activities of people as the realization of their abilities.

It should be emphasized that feudal privileges have always been guided by the principle of hierarchy, which determined social status. Because all the groups that make up society had a certain place in the hierarchical system, as well as various rights and privileges. Thus, since in society people knew no attitude other than command and obedience, privileges were naturally graded in a coherent hierarchy. It was believed that society should be built on a priori inequality before the law, and relations in everyday life were governed by hierarchy, which began in the family and ended at the highest levels, where there was a strict hierarchy between rulers. In this sense, inequality existed even among the nobles, with princes of royal blood and dukes having more rights before the law than petty nobles. And each of the existing classes was divided into additional subgroups and types. For example, nobility was divided into several types: princes of royal blood; titled nobles (including dukes, marquises, counts, barons) and ordinary nobles with predominantly military functions. While the third class was led by the highest government officials of non-noble origin; followed the various professions, financiers, large and small traders, craftsmen, rich peasant tenants, manual workers. In addition, each group had its own distinctive clothing and corporate privileges, which gradually faded to lower levels [4] (p. 40 - 41).

It is particularly important to note that the privileges were valued precisely because they were not accessible to all and emphasized belonging to one or another social group. Often they were connected not only with the person, but also with his property, which meant that not only the nobleman and the plebeian, but also their property had a different legal status. The privileges themselves could be corporate and non-corporate possession and were passed on either through the general nobility status or through land, titular and hereditary qualifications. In addition, the privileges were divided into seigneurial and noble, the former granting the nobles the power of lords over their possessions and the dependent population; and the latter gave them rights to political participation and exemption from certain obligations. $^{1}$

In turn, the two types of privileges are differentiated as follows:

I. Seigneurial privileges derive from the possession of the land and consist of: 1) the right to receivables in the form of private taxes and services; 2) patrimonial justice; 3) fulfillment of state obligations, such as collecting taxes and recruiting soldiers; 4) appointment of employees at the local level; 5) monopoly on the mills, wine presses, hunting, fishing and all underground and aboveground resources of the possession; 6) control over the movement, marriages and occupations of the dependent population.

II. Noble privileges were expressed in: 1) exemption from taxes; 2) the right to political participation, especially along the lines of participation in professional representative institutions, and the right to various services reserved exclusively for nobles; 3) badges of honor - coats of arms, titles, leading position in a public place and membership in military and knightly orders; 4) exclusive right to own land; 5) exemption from certain tax obligations; 6) hunting rights [4] (p. $40-41$ ).

In this context, an even more accurate idea of the content and scale of class privileges in the European type of feudal society can be obtained from the picture of classical French feudalism in the late eighteenth century.

In feudal France, two major classes enjoyed the greatest privileges - the nobility and the clergy. Before the French Revolution (from 1789 to 1793), these two classes numbered about 270,000, and the highest and best-remunerated services in the French feudal state were granted to the nobility. For example, the total number of services providing a noble title was 4000, and only in the period 1693 - 170940 thousand

\footnotetext{
${ }^{1}$ séniorat (Latin senioratus) (jur.) - inheritance law in some countries and epochs, according to which the land remains in the inheritance of the eldest of the family, so as not to be fragmented, while in the case of the major it passes to the eldest of the family; signoria (Latin) - land tenure of a feudal lord in the Middle Ages in Western Europe
} 
similar sinecure services were established [18] (p. 189; 192) something unseen at that time in Europe. And another curious fact about the French feudal privileges: from the sale of such sinecure services in the period $1701-1715$, Louis $\mathrm{XIV}^{\text {th }}$ has appropriated for himself 542 million livres "income" [8] (p. 33 - 34). Plus, the nobility of France used a permanent system to receive extraordinary gifts from the king, and vice versa - the king from the nobility. Only for the period $1774-1789$, for example, from the state treasury were distributed for pensions, gifts, etc. of the upper nobility about 228 million livres (then the currency in France), which is equal to about $60 \%$ of the total revenue of the state for one year then. And from this state treasure (amounting to 228 million livres) the royal family has appropriated over 80 million livres [8] (p. 33 - 34).

Of all the privileges enjoyed by the feudal class in the Middle Ages, the most striking are those relating to hunting and fishing. Feudal privileges of this nature are manifested in two ways: on the one hand, hunting has become a special kind of "feudal" sport as an exclusive noble right; and on the other hand, the serfs were obliged to make and preserve the game, for which the relevant regulations were issued.

The peculiarity of the privileges of the feudal nobility in France according to Al. de Tocqueville is that: first, once acquired, privileges become an irrevocable generic affiliation; second, the nobility possessed almost all the knowledge and wealth of society, owned its land and guided its citizens; and third, in this way it (the nobility) penetrated into the overall management of feudal society [18] (p. 35; 37; 186).

Many more and various credible things can be said about the scale and "wasteful element" of feudal privileges in politics, which have been revealed in a number of authoritative sources of science. Therefore, here as an additional illustration, we will give only a few striking examples of these privileges, which hardly have an analogue in world history.

One example stems from the little-known fact that the privileged classes in France were exempt from taxes, which led to the court's need for money leading to an even wider sale of services. Thus, for the Crown, their sale became an ordinary financial instrument that could be used whenever the need arose. In the last years of Louis $\mathrm{XIV}^{\text {th }}$ 's reign, this practice expanded considerably with a whole new class of services created solely to be sold. Thus the bureaucracy became huge, cumbersome and unmanageable, and the king resorted to the sale of certificates of promotion to a noble rank, which appeared in 1690 at a price of 6000 livres each. In this case, the direct purchase of a patent for nobility was nothing new, but the fact that it did not enjoy much prestige led those who wished to promote to a noble rank to resort to it as a last resort. However, it was far more practical to buy a post directly, which brought with it a noble status. In this way, the most expensive posts, which sold for about 100000 livres, secured hereditary noble status, provided they were worn for at least 20 years. And by the middle of the seventeenth century, most of the nobles of the mantle were in this category, while the lower positions (those in the field of finance and tax administration) were reserved for those who were satisfied with more moderate social growth, because not they were hereditary and were only personal. It should not be forgotten that most of the employees in the staff of the central and local administration did not receive fixed salaries, but formed their income in whole or in part from fees that they imposed on citizens to perform their duties. This, of course, created the possibility of abuses, and they were by no means uncommon in the practice of the Ancien Régime [3] (p. 97).

The other example is related to the total process of buying and selling almost everything in feudal France, which took place with the personal support (and participation) of the King. This process took two main forms: the sale of certain taxes to the so-called "tax collectors" and the sale of certain services to various individuals. For example, in the first half of the seventeenth century, the three main "taxes" (the gabelle, the "aides" and the so-called "five large farms" - cinq grosses fermes, which controlled the collection of duties after 1584) contributed more than $80 \%$ of the volume of all indirect taxes. In addition, in 1681 the various excises and duties were merged with the new tobacco monopoly, giving them to a syndicate of 40 tax collectors, known as "tax-farmers general", and it was planned to revise the amount of the purchase every six years. Here the main disadvantage of tax farming is more than obvious: left unchecked, tax collectors misappropriate much more of the revenue that passes through their hands than what is due to them, violating the interests of power. That is why half of the revenue never reaches the French government. And although in the eighteenth century attempts were made to move to the system of the so-called "regies" (in which the government pays the tax collectors salaries and bonuses), the resistance of stakeholders to this reform proved to be insurmountable. Therefore, the Headquarters of the collectors (Hötel des Fermes) has an unenviable reputation as "a huge devil's machine that grabs every citizen by the throat and sucks his blood out" [20] (p. 133 - 134).

The other example is related to the total process of the next tool on which the existence of the French Ancien Régime depends is the already known sale of services, for which we will give a few more shocking facts and data. This practice is called "second government debt" in the sense that the holder of the service invests some capital in it, the income from which is equal to the interest on a government bond. For example, by 1660 there were about 46000 employees, whose services had an average capitalization of about 419 million livres. That is, this system could have certain advantages from the point of view of the French monarchy. Because it is certain that the presence of so many employees means the presence of just as many dedicated people, committed to the maintenance of royal power, without which they would be absolutely nothing. However, its destruction would mean for them an immediate loss of the large sums of money with which they bought their posts [20] (p. $134-135)$.

The problems, however, stem from the fact that the fiscal costs of maintaining the system outweigh the benefits of it, because as early as 1639 , annual payments to service holders far exceeded revenues from sales of new services. This was the case at the time of the financier Colbert, when the Crown 
received 2 million livres in taxes on service holders, but paid them as much as 8.3 million livres in salaries, provided that he (Colbert) managed to liquidate about 20000 services [20] (p. 134 - 135).

And the last example of the rampant wheel- and- deal of the French absolutist royal power stems from the fact that the privileges granted for eternity have been constantly taken away. And if they could be reconciled with the troubles caused by such foolish damage, it would really be to mourn the fate of these new nobles, who in the seventeenth and eighteenth centuries were compelled again and again to buy their senseless honors or unjust privileges., paid repeatedly. Thus Louis XIV abolished all noble titles in the last almost 100 years, most of which had been bestowed by him. Of course, they could be retained only in one case: if they were paid for again, as these titles were acquired extraordinarily, as claimed in the edict by which they were approved [18] (p. 203 - 204). Naturally, not one or two entrepreneurs would envy this extremely "flexible business" then, although such and many other "state" mechanisms quite logically led to the collapse of the absolutist regimes in Europe (XVII-XVIII centuries), and thus of the total abolition of the hated political privileges after the victory of the Great French Revolution (1893). Or, in summary, the considered manifestations of political privileges in absolutist France permeated the entire social system of the country, were elevated to the rank of state policy and literally "eaten" all parts and mechanisms of the state machine. However, these privileges are fully justified historically, insofar as the then medieval feudal societies were at a low stage in their social evolution, in contrast to the later totalitarian socialist privileges.

At the risk of deviating somewhat from the present exposition, let us make a brief comparative description of the issue of the extent to which feudal political privileges find application in some modern social systems, and especially in the Bulgarian totalitarian state in the past twentieth century (1944 - 1989).

Regarding the total consumption of power privileges, their totalitarian followers did not lag behind after the establishment of the communist regime in the country (September 9, 1944). This happened immediately after the return of Georgi Dimitrov from the USSR (1945), who in the difficult conditions of the post-war deficit personally recommended the introduction of the system of the so-called "special supply" for the top party and government staff (following the Stalinist model) of the "socialist" republic [13] (p. 106). Thus, a part of the privileges of the political (nomenclature) elite are legitimized even during the initial domination of the regime, as a result of which a whole series of laws and regulations come, namely: 1) Law for Support to the Victims in the Fight against Fascism and Capitalism (SG, issue 224, 12.X.1944) with four subsequent additions: for permitting the illegal wives of the people's fighters (with whom they lived without marriage) to receive financial aid (from 1.VII.1945); for financial support of the supporters of guerrillas, relatives of the left intellectuals and the persecuted ethnic minorities (Jews and Gypsies) in the big cities (from
12.VIII.1945); for financial support for the blood relatives of the anti-fascist heroes up to the third degree of kinship and for the relatives by marriage up to the first degree of kinship (from 13.V.1945); and granting special sums to the minor brothers and sisters of the national heroes; 2) Ordinance-law for recognition of the rights of graduates in holding state, municipal and public service of writers and members of the Writers' Union who do not have higher education (from 24.X.1944) (it circumvents the Law on Positions, qualifications and salaries); 3) Ordinance - amendment and supplement to the "Regulations for appointment, transfer, layoff, dismissal (and for competitive examination) in high schools and high school classes", which determines a privileged order for the appointment of 11 categories of people - guerrillas and spouses of guerrillas; spouses and children of those killed by the fascist dictatorship; political prisoners and their spouses; the activesupporters of the guerrilla warfare; the unemployed due to accusations of leftism and anti-fascism, (...) as well as the teachers dismissed from other settlements with minimal school grade "Very good" (from 28.X.1944; Decree of the Council of Ministers for the creation of a true people's intelligence, which allows national heroes and their helpers to be admitted without exams (and without educational qualifications) in higher education, as the lack of secondary education is compensated by prior training of 6 to 12 months in the so-called "workers' faculties" (worfac) [1].

It should be explicitly noted that the Pensions Act of 1957 defines pensions for special merits and personal pensions (personally granted government pension during one's public service career), the amounts of which exceed many times the amounts for disability, for example. There are three privileged categories determining the amount of the personal: one refers to members of the central, regional or district leaderships of political and anti-fascist organizations, as well as to associates of the central leadership, including commanders, chiefs of staff and political commissars. or quartermasters of brigades, companies and detachments and their deputies; the second group includes members of the leaderships of the political and anti-fascist organizations in the districts and regions, as well as associates of the regional and district leaderships, incl. detachment commanders, political commissars and their deputies; and the third category includes other participants in the struggle against fascism and capitalism [1].

To what has been said about these privileges we will add a few more striking facts: first, they, the privileges, were additionally "legalized" in the distant 1956, when the party leadership in Bulgaria legitimized them with Protocol "A" of the Politburo, and two years later also adopted Decision "B-12" of the Secretariat of the Central Committee of the Bulgarian Communist Party for the establishment of an uncontrolled fund for the maintenance of those in power in the country; second, in 1963 the Politburo of the Central Committee of the Bulgarian Communist Party took new decisions (reflected in Protocol B-13) to improve the work of guarding, supplying and servicing the top party and state nomenclature (as well as the delegations and guests of the party and government); and third, by virtue of these 
"regulations", that is, the protocols, the care of the highest party-state echelon was entrusted to the Department for Safety and Protection (DSP), which diligently fulfilled all nomenclature privileges and whims (from free food to the upper elite to the empty planes that used to babysit them around the world at the people's expense).

However, there is another drastic fact from the Bulgarian totalitarian reality, which can hardly be found in other countries of totalitarian socialism. It refers to the personal privileges of a social caste created by the regime, called "active fighters against fascism and capitalism" (AFAFC).

This privileged group of breadwinners of the Bulgarian totalitarian society benefited from a personal insurance "made" for it, which differed significantly from the general procedure for retirement of all other citizens of the country. Privileged comrades holding this title received three types of pension from the state treasury: one - for lenght of service and old age; another one - the so-called "personal"; and a third one called the "survivors personal". The total number of persons receiving these three types of pensions as of 31.XII.1989 was 73258 , of which 45830 were purely privileged personal and survivors "personal" pensions for persons declared AFAFC [5] (p. 180).

By the way, we will add that the privileges of the nomenclature class have so deeply covered the various social spheres that in 1969 an Ordinance on the use of public baths was adopted, which contained special clauses for folk heroes: children under 5 years and AFAFC have the right to free use of the public baths, free sheet and free cabin in the bathroom, etc. [5]. And all this on the condition that the bath ticket then costed some BGN 0.05!??! In the Ordinance it is forgotten to mention whether the calves in the public baths will rub the weary nomenclature bodies against payment or for free!!??!

With the exception of the privilege for a certain category of people, the two types of "personal" pension have a very impressive quantitative dimension. The expenditures of the state budget for their payment in 1989, for example, amount to BGN 45 million. However, this is an amount "granted" from the state budget for only one year, and the same pensions have been received for nearly 20 consecutive years. During these 20 years of "action" of this special advantage (1970 - 1989) for the two types of "personal" pension the state treasury spent a huge amount of BGN 749 million at the then prices! [5] (p. $180) \ldots$ This is also the price that the people had to pay for the "special merits" of this very special stratum of society. Because in the country at that time only pensions were periodically updated with special decrees and edicts, as, by the way, happened with all the privileges of the nomenclature class and its satellite strata.

Excluding the privilege for a certain category to illustrate everything said about the totalitarian privileges of the communist nomenclature, we will cite a few more facts from the interesting book by K. Lalov and V. Veleva "Power, money, communism", which objectively reveal on the basis of rich documentary material. the vicious nature of these privileges. Here are the striking facts that the authors are dealing with: first fact - "... for the period 1979-1989 from the cash desk of
DSP were distributed to management staff according to their position and paid by hand personally (...) BGN 2860 039" (for food of the higher nomenclature - author's note); second fact for the period 1985-1989 under a light regime the top management of the Bulgarian Communist Party bought 51 western cars, for which BGN 702719 were paid, while the market value of the cars was BGN 3624 256, as "only under this item the eligible authorities have damaged the state with BGN 2921 537!"; third fact - for the years 1968 - 1989 from the secret extra-budgetary accounts of the service "Financing of the special departments" of the "first" authorities are "paid representative funds in the amount of BGN 17804 850" [10] (p. 36; 39; 84) (emphasis is mine - G. M.). Moreover, the amounts have been increased several times during these 21 years, without any changes in the famous protocols of the Politburo!!!

The total recapitulation of the above three obvious facts about the size of only these totalitarian privileges of the nomenclature shows the colossal figure of BGN 23586426 , which is really shocking because it was just "snatched" illegally from the state budget of the country.

In summary, the system of privileges of the nomenklatura class (and elite) in the totalitarian "socialist" society spreads in 7 main spheres of social life with a total of 34 types of special privileges, starting from the cradle and ending at the grave. Moreover, although some of these privileges were clad in legal armor, they degenerated to such an extent that they became exclusive rights (and advantages) only to a narrow circle of the political (nomenclature) oligarchy in our country, which, without any special merit, determined for itself the scale, types and dimensions of totalitarian political privileges. That is, as Prof. Milcho Lalkov rightly points out, immediately after September 1944 the foundations were laid for "... the formation of an essentially unconstitutional and inhumane system of privileges, which benefits certain categories of citizens and opposes them to the main part of society" [9] (p. 54). And what is even more unpleasant: this illegitimate system of nomenclature privileges under "socialism" not only differs in almost nothing from feudal political privileges, but in many respects surpasses them both in scope and in fulfilled "content" in all social spheres.

And one more thing to conclude: both feudal and totalitarian political privileges are far from any kind of social equality and justice, which is why they were logically rejected by people and societies in the respective historical epochs.

\section{Basic Conclusions and Summaries}

The analysis shows that the phenomenon of "political privileges" has always had a very strong presence in all social formations, and especially in the feudal absolutist regimes in the seventeenth and eighteenth centuries. Depending on this, several fundamental conclusions (and summaries) concerning the nature and future of these privileges emerge, which are:

First. Regardless of the nature of the political system in the country (authoritarian, totalitarian, etc.), political privileges have always been extremely diverse, numerous and inflated, 
which in most cases is in dissonance with any constitutional and legal provisions.

Second. Privileges in feudal absolutist society in the Middle Ages (and especially in the Late Middle Ages) were something quite natural and regular due to the sharp social class differentiation of different social groups (and strata) aristocracy, clergy, nobility, bourgeoisie, peasantry and others. Therefore, they fully benefited the dominant and ruling feudal-oligarchic classes.

Third. Feudal political privileges in the Middle Ages had one very important feature: they were respected, valued, and maintained because they distinguished the affiliation of certain social groups above other classes in society. In other words, they were in most cases a sign of belonging to the rich and aristocratic classes in the state (clergy, nobility, etc.), which distinguished them from all other social groups, classes and strata.

Fourth. Privileges in general are the complete antithesis of equality in society, and in this sense absolutist political privileges are a gross violation and disregard for political equality and disregard for any human rights in the Middle Ages.

In our time, political privileges have long since acquired a legitimate character, because in democratic political systems they are legalized and regulated according to the respective hierarchical positions in the legislature, government, etc. However, in a number of democracies, there are still some privileged elites who enjoy too many benefits due to their high positions in government. An indisputable fact that again and again the question of the so-called "Political justice" raises and the equality of people in politics (political equality), on which there is some serious contemporary research $[1,7,12,14,17$, 21], but nevertheless these benefits continue to "reproduce" inequality between elites and tables. However, this is a problem that is not the subject of this article because it needs much more special, different social sciences.

\section{References}

[1] Vasiliev, L. S. The phenomenon of feudalism. [online]. [reviewed 12.05.2021]. http://ecsocman.hse.ru/data/2010/12/01/1214822750/Vasiliev. $p d f$.

[2] Vodenicharov, P. Social care and privileges for the elite. Critique of the social policy of the totalitarian Bulgarian state. [online]. http://www.history. swu.bg/pv.pdf.

[3] Gavrilov, B. (1999). The century of absolutism $1648-1788$. Sofia: LIK magazine, p. 31-32.

[4] Gavrilov, B. (2011). History of the New Age. Sofia: St. K. Ohridski, p. $40-41$.
[5] Gribachev, D. (1997). The drama of socialism in the twentieth century. Plovdiv, p. 176-177.

[6] SG, issue 100, 26. XII. 1969.

[7] Emanuilov, Aleksey. (2014). Privileges in Russia in the 18th 19th century. - In: Bayl Bog. Sochi, Anton Makarenko State University, 2014, p. 369-371. ISSN 2073-9745. [online]. https://www.webofscience.com/wos/woscc/summary/9/relevan ce/2-position 66 .

[8] Kautsky, K. (1919). class contradictions in the French Revolution. p. 33-34.

[9] Lalkov, M., L. Ognyanov. (1992). People's democracy or dictatorship. Sofia, p. 54.

[10] Lalov, K., V. Veleva. (2007). Money, power, communism. Sofia: Trud, p. 36; 39; 84.

[11] Manolov, G. (1995). Stalinism as a model of a totalitarian society. Plovdiv, p. 65-67.

[12] Neshev, Kiril. (1992). The love of power. - In: Sociological problems, Sofia: BAS, 24, 1992, p. 30-39. [online]. https://www.ceeol.com/search/previewpdf?id $=13533$.

[13] People's Republic of Bulgaria from beginning to the end. (2011). Sofia: Ciela, p. 106.

[14] Essays on the history of the USSR: The period of feudalism the end of the 15 th century - the beginning of the 17 th century. [online]. [reviewed 12.05.2021]. https://elib.bsu.by/bitstream/123456789/159769/1/4.\%20\%D0 $\% 9 \mathrm{E} \% \mathrm{D} 1 \% 87 \% \mathrm{D} 0 \% \mathrm{~B} 5 \% \mathrm{D} 1 \% 80 \% \mathrm{D} 0 \% \mathrm{BA} \% \mathrm{D} 0 \% \mathrm{~B} 8 \% 20 \%$ D0\%B8\%D1\%81\%D1\%82\%D0\%BE\%D1\%80\%D0\%B8\%D $0 \% \mathrm{~B} 8 \% 20 \% \mathrm{D} 0 \% \mathrm{~A} 1 \% \mathrm{D} 0 \% \mathrm{~A} 1 \% \mathrm{D} 0 \% \mathrm{~A} 1 \% \mathrm{D} 0 \% \mathrm{~A} 0 . \% 20 \% \mathrm{D} 0$ \%A2.\%205.\%20\%D0\%A1.\%20743-751\%20(1955).pdf.

[15] Petrov, N. (2017). National security. p. 35.

[16] Pushkarova, Iva. Privileges in the totalitarian state. [online] www. justicedevelopment.bg, p. 2-3.

[17] Rosanovich, D. J. Remarks on Hegel's concept of "privilege". [online]. [reviewed 12.05.2021]. https://revistas.ucm.es/index.php/RPUB/article/view/54995/50 115.

[18] Tocqueville, Al. de. (1992). The former regime and the revolution. Sofia: Izbor, p. 189; 192.

[19] Tumbaeva, I. (1990). Privileges in a Socialist Society: Are they needed? - In: Economic Sciences, № 3, p. 59-60.

[20] Ferguson, N. (No year). Money and power in the modern world (1700 - 2000). The monetary connection. Sofia: Riva, p. 133134.

[21] http://www.attali.com. 